\title{
An Evaluation of the Focus-on-Form Instruction Taken to Raise Students' Grammatical Awareness in the EFL Textbook Employed in Secondary Schools of Zhejiang, China
}

\author{
Li Lu-yao \\ University of Exeter, Exeter, UK
}

\begin{abstract}
This essay will focus on the evaluation of the English as a foreign language (EFL) textbook used in Zhejiang Province of China, to evaluate whether the book reflects the focus-on-form (FonF) instruction, and how teachers utilize the book to raise students' grammatical awareness in class. First, the rationale of this topic will be introduced in the introduction part. Second, a brief literature will be reviewed and theoretical supports will be provided in the evaluation section. Third, Chinese context, especially the context of Zhejiang Province, will be analyzed briefly to help readers better understand the background of the EFL textbook and education policy. Fourth, some criteria will be developed according to literature review and context section to evaluate the textbook, and how to raise students' grammatical awareness will also be figured out.
\end{abstract}

Keywords: evaluation, English as a foreign language (EFL) textbook, Zhejiang Province, focus-on-form (FonF) instruction, grammatical awareness

\section{Introduction}

The discussion of how to teach linguistic forms, especially grammar, keeps continuing to take a great position in language pedagogy (Ellis, Basturkmen, \& Loewen, 2002). With the rise of the communicative language teaching (CLT) approach in the 1970s and the early 1980s in speaking English as a second language (ESL) countries, the controversy about traditional grammar teaching methods (e.g., grammar translation method and audio-lingual method) rebounded in China. As Hu (2002) presented, China conducted a reform in English language teaching in the late 1980s, and CLT was introduced into this reform. However, according to his research, CLT has not attained expected impact. As a big supporter of improving students' communicative competence, Hu's research was out of the author's expectation, and also arouses her to think about practical ways to learn and use grammar both fluently and accurately. The growing discussion of an integrated teaching form to the context of communicative activity by researchers (e.g., Doughty \& Williams, 1998 (as cited in Ellis et al., 2002); Long, 1991; 1996 (as cited in Kumaravadivelu, 2005)) interests the author and also provides her a new angle of grammar teaching.

This essay is going to be divided into four parts. First, a brief review of different types of instruction will be given, i.e., focus-on-meaning (FonM) instruction, focus-on-forms (FonFs) instruction, and focus-on-form (FonF) instruction, which will be occupied in major proportion. Second, the context in Zhejiang Province will 
be introduced, relating the context to FonF instruction. Third, the textbook Go for It! (Grade 7/Part 2), which is adopted by Zhejiang public secondary schools, will be evaluated. Finally, conclusions will be made to summarize and highlight main ideas.

\section{Literature Review}

The controversy of whether grammar should be given priority attention in language instruction, or be excluded, or be subordinated to meaning-focused use of the target language has been lasting for more than 2,000 years (Nassaji \& Fotos, 2004). Based on the ongoing debate and previous research, which will be reviewed in further detail below, Ollerhead and Oosthuizen (2005) presented three different types of second language (L2) instruction, i.e., FonM, FonF, and FonFs instruction.

\section{FonM Instruction}

FonM instructional approach means that language learners can acquire the target language through natural exposure, not formal instruction. It was approved by studies on the acquisition of English morphology (Bailey et al., 1974; Dulay \& Burt, 1974; as cited in Nassaji \& Fotos, 2004). The results claimed that the process of first language (L1) and L2 learning are similar, in other words, if L1 learners can learn language without formal instruction, L2 learners also can learn language in this way (Krashen, 1981; Schwartz, 1993; Zobl, 1995 (as cited in Nassaji \& Fotos, 2004)). Based on that, various characteristics of L2 classrooms were presented, such as "those implementing Prabhu's procedural syllabus, Krashen and Terrell's Natural Approach, and some (but not all) content-based ESL instruction and immersion education" (Long \& Robinson, 1998 (as cited in Doughty \& Williams, 2008, p. 19)). However, the immersion programs, for example, in Canada, failed to acquire the expected results. That is to say, learners may not achieve a high level of linguistic competence through a purely meaning-focused environment, thus some researchers, such as Swain (1995) (as cited in Ellis et al., 2002), suggested that in L2 class, linguistic form should be engaged in communicative activities (Ellis et al., 2002).

\section{Form-Focused Instruction (FonF and FonFs)}

According to Long (1991) (as cited in Ellis et al., 2002), there are two kinds of form-focused instruction can be identified: One is FonFs, and the other is FonF. The former is a traditional language teaching approach which isolates or extracts linguistic features from context or communicative activity (Doughty \& Williams, 2008). In other words, the main attention on FonFs instruction is on the form of the target language (Ellis et al., 2002). Whereas, the effectiveness of the FonFs instruction was obviously reduced when this was measured in the light of learners' competence to use target form spontaneously in communication (Norris \& Ortega, 2000 (as cited in Ellis et al., 2002)). This forced the FonF instruction. The primary attention of FonF instruction is integrating the linguistic form or features into a meaningful context (Ollerhead \& Oosthuizen, 2005; Doughty \& Williams 2008, p. 3; Long \& Robinson, 1998 (as cited in Doughty \& Williams, 2008, p. 22); Ellis et al., 2002). Comparing with FonM and FonFs, FonF is more eclectic. It is motivated by Interaction Hypothesis which holds the opinion that "L2 learners can acquire the language through neither a purely linguistic nativist, nor a purely environmentalist theory" (Long \& Robinson, 1998 (as cited in Doughty \& Williams, 2008, p. 22)).

Planned FonF and incidental FonF. Ellis et al. (2002) claimed that there are two types of FonF instruction can be distinguished - planned FonF and incidental FonF. "The former involves the use of focused tasks, i.e., communicative tasks that have been designed to elicit the use of a specific linguistic form in the context of meaning-centred language use" (Ellis et al., 2002). Thus, to some extent, planned FonF is effective 
because the specific forms will be repeated through learners' communication, while incidental FonF instruction is more extensive, which means that the communicative tasks are designed to elicit general linguistic forms instead of specific forms. According to Ellis et al. (2002), there are some similarities and differences between planned FonF and incidental FonF instruction:

(a) Similarities:

1. The use of a communicative task is required;

2. Communicative tasks are designed to elicit the use of linguistic forms;

3. The primary focus is on meaning;

4. People who learn L2 are regarded as "language users" rather than "learners";

5. L2 users do not aware the target form.

(b) Differences:

1. Communicative tasks in planned FonF are designed to elicit specific forms, while in incidental FonF, general forms are in focus;

2. Performing tasks is different, planned FonF is pre-determined, whereas the incidental one is occasional;

3. The attention to the form of FonF instruction is intensive, while the other is more extensive;

4. With incidental FonF, various linguistic forms compete for the learners' attention, however, with planned FonF, teachers can elect the linguistic form which should attract learners' attention;

5. There are two ways can be done in planned FonF, which are input flooding (i.e., numerous input of the target language without obviously drawing attention to it) and input enhancement (i.e., during the input procedure, teachers highlight the target features and draw learners' attention to them).

Reactive FonF and Preemptive FonF. "Two kinds of FonF can be identified whether the FonF is planned or incidental: reactive and preemptive" (Long \& Robinson, 1998 (as cited in Ellis et al., 2001)). As far as Ellis et al. (2001) are concerned, reactive FonF occurs in the procedure when "an actual or perceived error" is contained in an utterance that is produced by L2 learners, which could be addressed by teachers, also by some learners through providing negative feedback. According to Long and Robinson (1998) (as cited in Marzban \& Mokhberi, 2012), this feedback can be explicit, which means that learners are told directly of the error or are given meta-lingual information relating to the correct form, or also can be implicit, which means that the learner acquires the target language form by giving recast.

Although preemptive FonF is problem-oriented as reactive FonF, the nature of the problem is different. In preemptive FonF, it involves the teachers or learners "initiating attention to form even though no actual problem in production has arisen" (Ellis et al., 2001). The problem here is more like information gap which seems to be problematic. There are two types of preemptive FonF, one is student-initiated preemption, and the other is teacher-initiated preemption. The former means that the gap is addressed by learners, which could reflect students' real needs and be more motivated; however, it is easy to detract from communicative activity. The latter is that teachers make decisions about what kind of gap should be focused, while this gap might not reflect the actual gap that exists in learners' knowledge (Ellis et al., 2002).

As mentioned above, there are several options for accomplishing FonF instruction. As far as the author is concerned, the situation of different classes is various, and any single class might involve one or more options. Thus, the author claims that teachers will play an important role in choosing and combining various options together based on their own context, and keeping the positive attribute of each instruction, while removing the 
negatives. Based on this opinion, the author concludes some principles which will be reflected in her evaluation of a textbook section:

1. Communicative language use and grammar instruction should be combined;

2. Instruction should be based on learners' needs;

3. In order to rise students' grammatical awareness, explicit and implicit feedback could be integrated;

4. Teachers select instruction flexibly according to their class context.

According to Van Reybroeck, Delaere, Hupet, and Schelstraete (n.d.), the definition of grammatical awareness can be defined "as an explicit knowledge about the grammatical attributes of language. It can be viewed as composed of two abilities: syntactic awareness and morphological awareness". This awareness seems more explicit and concrete which focuses more on rules and structures. In contrast, grammatical awareness in this essay is more implicit and abstract. As mentioned above, traditional grammar methods normally focus on forms, the underlying assumption could be that grammar is extremely important; in other words, the grammatical awareness under those methods must be emphasized much. However, this awareness may solely focus on learning and remembering grammar by drilling it, rather than using it. Thus, here the grammatical awareness is letting students know how to use grammar in communicative activities, and also making learners notice the grammatical attributes during the communicative activities. As Tomlinson (2003) (as cited in Bolitho, Carter, Hughes, Ivanič, Masuhara, \& Tomlinson, 2003) defined, language awareness is a mental attribute which helps learners gain insights into the language, and this awareness is more internal and gradual. Based on the theory, grammatical awareness in this essay also focuses more on internal, and which could be "heathier" than traditional awareness.

\section{Context in Zhejiang Province}

Zhejiang Province, as a part of China, has a common context as other Chinese areas, and has its own characteristics. Therefore, a brief description in the context of whole China will be given, then, the focus will be shifted to Zhejiang province. FonF instruction is more based on speaking ESL countries, while China is a speaking English as a foreign language (EFL) country, whether it is applicable in China still exists debate. According to Wang (2009), more and more Chinese scholars (e.g., He \& Wang, 2004; Zhang, 2006; Gao \& Li, 2006) have been concentrating on the notion of FonF instruction. As he proved, the FonF instruction exists in Chinese secondary English class, which means that although many research of FonF instruction focuses on speaking ESL countries, the instruction also exists in China. Because this instruction is intended to induce L2 learners to pay attention to linguistic form through communicative activities, even though it may has not been paid much attention to or been a primary English teaching approach, it will be a hot research field in the future. There are three reasons as follows:

1. The debate of traditional grammar teaching methods (e.g., grammar translation method and audio-lingual method) has never been stopped. The disadvantages of them are obvious, such as students will over-focus on grammar structures and rules completely, thus neglect how to use them in communication;

2. Seen from the new standards of English education at primary and secondary schools in China, and also from the tendency of English education reform (Wang, 2009; Hu, 2002), improving learners' communicative competence is becoming more and more important;

3. With the increasing demand of people with a good command of English, not only in writing and reading, but also in listening and speaking, the thinking of reforming English teaching will be aroused to cater the trend 
of employment market demand.

Zhejiang Province is considered as a developed area in China, cities like Ningbo, Hangzhou, Wenzhou have a large demand of English personnel, which leads to the reform in English education in that area is relatively urgent. According to English Curricular Standards in the Phase of Compulsory Education (Ministry of Education of the People's Republic of China, 2011), one of the syllabus aims emphasizes the procedure of learning and pays attention to developing the ability of communicating with others in English. In this concept, syllabus designers claimed that students should learn, understand, and use English based on the real language context, which encourages students to master language knowledge and skills under the instruction of teachers. This reflects the FonF instruction to some extent. The new syllabus not only focuses on linguistic form learning, but also highlights the practicability and effectiveness of language learning through communicative activities by creating real-like language environment in class by language teachers. In other words, it can be seen as a combined linguistic form with meaning through communicative activities. And, the new curriculum also advocates teaching the English language based on students' future development, to help students have a good foundation to study further in English subjects, and also to cultivate their intercultural awareness. In other words, it embodies language learners' needs.

Although the demand is huge, the curriculum reform is in progress, and the new curriculum seems to conform to both learners' needs and the trend of the times. But, there still have some problems which may impede the pace of the reform. For example, most language teaching is test-driven, which is easy to fall into the traditional teaching mode again (for example, in grammar teaching, teachers may still adopt grammar translation method); large class size may mitigate against teacher supervision of pair or group practice, and the implication is that without supervision, learners may not use the target language in communicative activities (Fotos, 1998).

\section{Textbook Evaluation}

In this section, the English textbook Go for It! (Grade 7/Part 2) (People's Education Press, 2013) will be evaluated. As mentioned above, teachers play an important role in selecting appropriate instruction in class, so not only the textbook, but also teachers' behavior, will be evaluated.

\section{Brief Description of the Textbook}

This textbook is used in public secondary schools of Zhejiang Province. Here, the author first described the layout and the stated aim of this textbook, and then she selected "Unit 12: What did you do last week?" as a typical extract to focus on her evaluation which relates to the criteria (see Appendix).

The aims of this textbook are to let students master some basic English language knowledge, develop their English skills, namely, listening, speaking, reading, and writing, cultivate their communicative competence, and promote the development of thinking ability. More specifically, this textbook is based on different topics (such as holiday, food, weather, etc.), and embodies linguistic knowledge and communicative skills, to guide students to study, realise, acquire, and use English in their real life gradually. The organization and content of the textbook is according to the aims. There are 12 units in this book (see Appendix), and each unit consists of two parts (i.e., Section A and Section B) with different knowledge points. Section A, which includes new vocabularies, solidifies the vocabularies and presents new grammar structures through listening and communicative activities (such as group work and role-play). After that, there will be a "Grammar Focus" table 
to conclude the grammar structures and rules in this unit. Then, followed by some exercises, for example, filling in the blanks and group/pair work, grammar knowledge will be consolidated. In Section B, there will be listening, reading, speaking and writing (four skills) activities to not only consolidate the knowledge taught in Section A, but also improve students' four skills. At the end of Section B, there is a "Self Check" part checking whether the students master the knowledge or not.

\section{Objectives of Unit 12}

Objectives of Unit 12 can be divided into the objectives of target language knowledge and the objectives of emotion manners and value. The objectives of the target language knowledge in this unit are as follows:

(a) Mastering new vocabulary;

(b) Mastering simple past tense sentence structures;

(c) Knowing how to use simple past tense in real life conversations.

The objectives of emotion manners and value are as follows:

(a) Helping students learn how to cooperate with others;

(b) Describing the weekend, guiding the students to notice their life;

(c) Improving students' ability to study independently;

(d) Nurturing students' imagination;

(e) Encouraging students to learn knowledge of nature;

(f) Helping students manage their time well.

\section{Evaluation Criteria and Evaluation of Unit 12 Section A}

In order to well evaluate the textbook and teachers, some criteria were developed as follows:

1. Whether the content of the textbook is close to life and can be used in life. From the author's perspective, the reason to set this criteria is that the content of the textbook based on life can not only arouse students' interest and motivate them, but also be more practical for teachers and students, which because there will be more materials to adopt and topics to talk. In Unit 12 Section A, the main topic is about students' weekend, which encourages them to share their life in class and makes them pay attention to their daily life.

2. Whether the textbook reflects the requirement of the syllabus aim. The syllabus aim reflects the country's policy and tells the general direction of the English education, which will bring a great influence on each teaching procedure. Therefore, whether the textbook can reflect the syllabus aim is very important. As mentioned above, one of the aims is to develop students' communicative competence and also improve their four skills (i.e., listening, reading, speaking, and writing). From the organization of this unit, it can be seen that it covers all those skills practice, particularly, the listening part and speaking part are occupied in great proportion. From that, it is clear that the textbook reflects the syllabus aim. While, the problem is not about the textbook, but about the practice. The attitude of teachers could be a problem. If a teacher has much experience in teaching and gets used to adopt the traditional pedagogy, he/she may not be willing to change his/her teaching process too much; or may because he/she does not know much about FonF instruction and pays attention to form and meaning in communicative context, this will have a negative effect on the efficiency of using the textbook. In this situation, schools could increase opportunities to do more teacher training and help teachers absorb advanced and various teaching methodology.

3. Whether the textbook meets the students' needs. As Brown (1995, p. 217) presented, needs analysis is one of the important and necessary elements that should be considered in syllabus design. Because of the huge 
demand of English personnel, the important status of English in various tests (for example, the International English Language Testing System (IELTS), Test of English as a Foreign Language (TOFEL), and university entrance exams), and the increasing number of students who want to study abroad, therefore, students' needs in learning English is becoming stronger. In this respect, the textbook satisfies students' needs to a certain degree. While, one of the potential problems will arise when it is used in real class. It is obvious that the content of the textbook is informative, trying to improve all four skills, whereas the class period is limited (40-45 minutes per class), which might increase the burden of students.

4. Whether the content of textbook integrates the form or linguistic features into a meaningful context. From literature review, it shows that comparing with FonFs instruction and FonM instruction, the FonF instruction can relatively well balance the relationship between form and meaning. In this unit, first, it sets a topic about last weekend, then, through listening and speaking parts, to help students learn new vocabulary and sentence structure, which combines form and meaning in a real-like context based on real life through some communicative activities (role-play and dialogue). In this respect, the textbook meets the criterion. While, the problem could be whether the communicative activities be adopted well in class. For example, there are three role-play games in Section A. On one hand, it highlights the intention of improving students' communicative competence; on the other hand, it seems become more formulaic. Same games and repeated knowledge points may make both the teacher and students feel bored, and may cannot receive expected results. Under this circumstance, textbook designers can introduce a variety of activities, and the teacher also can adjust the activities according to his/her own teaching procedure.

5. Whether the teacher could use appropriate instruction and feedback to improve grammatical awareness. One type of this instruction is planned FonF that focuses on specific forms. There are two ways to be done in it: input flooding and input enhancement. In Unit 12, the specific grammar point is simple past tense, as we can see clearly from the title, while students may not know the terminology of this grammar. From the textbook, "Grammar Focus" part is at the end of Section A, before that, there is much input of using simple past tense through listening and speaking activities. It is like "input flooding". In addition, when students get used to know some basic features of simple past tense, the "Grammar Focus" part highlights the grammar and draws students' attention to it, which can be considered as the representative of "input enhancement". Here, the teacher plays a crucial role in using the instruction. If the teacher introduces the grammar rule at the beginning of the class rather than doing enough input to draw students' attention to simple past tense naturally, the planned FonF instruction will make no sense.

Moreover, the teacher also will affect the way to raise students' grammatical awareness. In literature review, the author mentioned several options of accomplishing FonF instruction, which includes reactive instruction and preemptive instruction. According to Ellis et al. (2002), reactive FonF "is the teacher or another student responds to the error that a student makes in the context of a communicative activity", one of the practical ways is by giving feedback. Taking 3c of Section A as an example, the activity is called "drawing something". During the activity, the teacher can pay attention to the target grammar points, and select appropriate ways to give feedback when errors arise. One way is giving implicit feedback, here the teacher can first repeat the error by rising intonation and stress to highlight students' error and try to draw their attention to it, or by recasting when students fail to self-correction. Implicit feedback can correct errors naturally, but it might easily distract students' attention from communicative activities, because the feedback is much more 
intrusive (Ellis et al., 2002). Another way that could be used when errors come out during the activity is explicit feedback by directly correcting it or using metalanguage to draw students' attention to errors. The advantage of this feedback is emphasizing the errors straightforwardly and students might have clear memory; however, it might pose a risk to students' dignity. Based on the above, during the communicative activity, the teacher has great latitude to select different ways to accomplish FonF instruction. In addition, no matter the feedback is implicit or explicit, the main intention is to make students notice and pay attention to error-prone grammatical attributes, and this "attention", to some extent, can be perceived as one form of grammatical awareness.

\section{Conclusion}

Based on the above evaluation of the textbook, the results indicate that it meets students' needs, reflects syllabus aims, combines form and meaning in communicative activities, and is close to life, thus, it can be considered as an applicable textbook in Zhejiang Province. Whereas, there still have some potential problems. For example, the content is too informative, especially lacking enough class period; and the form of communicative activities is monotonous. As the author emphasized before, the teacher is a crucial element in using FonF instruction in class and adopting appropriate ways to raise students' grammatical awareness, such as giving implicit and explicit feedback through communicative activities. The FonF instruction has many manifestations, and these manifestations can link together more or less. Additionally, one class and one textbook cannot only include one instruction, therefore, the author thinks that mixed methods instruction could enhance advantages and avoid disadvantages from each instruction.

\section{References}

Bolitho, R., Carter, R., Hughes, R., Ivanič, R., Masuhara, H., \& Tomlinson, B. (2003). Ten questions about language awareness. ELT Journal, 57(3), 251-259.

Brown, J. D. (1995). The elements of language curriculum: A systematic approach to program development. Boston, M.A.: Heinle \& Heinle Publishers.

Doughty, C., \& Williams, J. (2008). Issues and terminology. In C. Doughty, \& J. Williams (Eds.), Focus on form in classroom second language acquisition (pp. 1-11). New York, N.Y.: Cambridge University Press.

Ellis, R., Basturkmen, H., \& Loewen, S. (2001). Preemptive focus on form in the ESL classroom. TESOL Quarterly, 35(3), 407-432.

Ellis, R., Basturkmen, H., \& Loewen, S. (2002). Doing focus-on-form. System, 30(4), 419-432.

Fotos, S. (1998). Shifting the focus from forms to form in the EFL classroom. ELT Journal, 52(4), 301-307.

Freeman, L. D. (2013). Grammar. In D. Nunan, \& R. Carter, (Eds.), The Cambridge guide to teaching English to speakers of other languages (pp. 34-41). Cambridge, U.K.: Cambridge University Press.

Hu, G. (2002). Potential cultural resistance to pedagogical imports: The case of communicative language teaching in China. Language Culture and Curriculum, 15(2), 93-105.

Kumaravadivelu, B. (2005). Understanding language teaching: From method to postmethod. Mahwah, N.J.: Lawrence Erlbaum Associates, Inc., Publishers.

Long, H. M., \& Robinson, P. (1998). Focus on form: Theory, research, and practice. In C. Doughty, \& J. Williams (Eds.), Focus on form in classroom second language acquisition (pp. 15-41). New York, N.Y.: Cambridge University Press.

Marzban, A., \& Mokhberi, M. (2012). The effect of focus on form instruction on intermediate EFL learners' grammar learning in task-based language teaching. Procedia-Social and Behavioral Sciences, 46, 5340-5344.

Ministry of Education of the People's Republic of China. (2011). Compulsory education English curriculum standard. Retrieved from http://mat1.gtimg.com/edu/pdf/edu/xkb2011/20120130155515499.pdf (In Chinese)

Nassaji, H., \& Fotos, S. (2004). Current developments in research on the teaching of grammar. Annual Review of Applied Linguistics, 24, 126-145. 
Ollerhead, S., \& Oosthuizen, J. (2005). Meaning-focused vs. form-focused L2 instruction: Implications for writing educational materials for South African learners of English. Stellenbosch Papers in Linguistics, 36, 59-84.

People's Education Press. (2013). Go for it! (Grade 7/Part 2). Retrieved from http://www.wsbedu.com/wu51/keben-624-ben.html

Richards, C. J. (2005). Addressing the grammar gap in task work. In C. J. Richards, \& A. W. Renandya (Eds.), Methodology in language teaching - An anthology of current practice (pp. 153-167). New York, N.Y.: Cambridge University Press.

Swan, M. (2005). Seven bad reasons for teaching grammar and two good ones. In C. J. Richards, \& A. W. Renandya (Eds.), Methodology in language teaching-An anthology of current practice (pp. 145-148). New York, N.Y.: Cambridge University Press.

Van Reybroeck, M., Delaere, S., Hupet, M., \& Schelstraete, M. (n.d.). Grammatical awareness and grammatical spelling: Comparison of children with and without dyslexia. Retrieved from http://www.bcbl.eu/events/IWORDD/en/speakers/desde $0 /$ ver/1406/

Wang, L. Y. (2009). "Focus on form" or "focus on forms"? - A study of English classrooms practice of a Chinese secondary school (Master's thesis, Dongbei Normal University, China). Retrieved from http://www.taodocs.com/p-4701181.html (In Chinese) 
Appendix: Photo Copies and 12 Units of the Textbook

Photo Copies of Unit 12
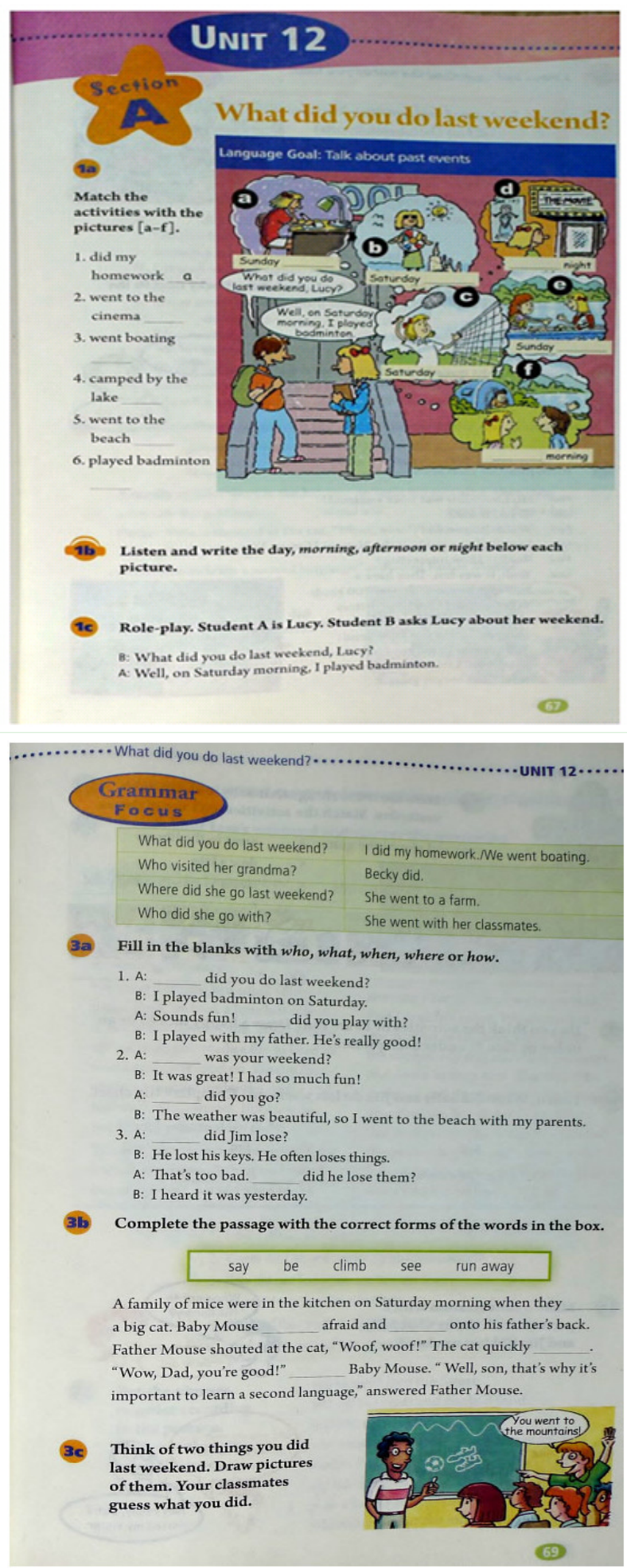
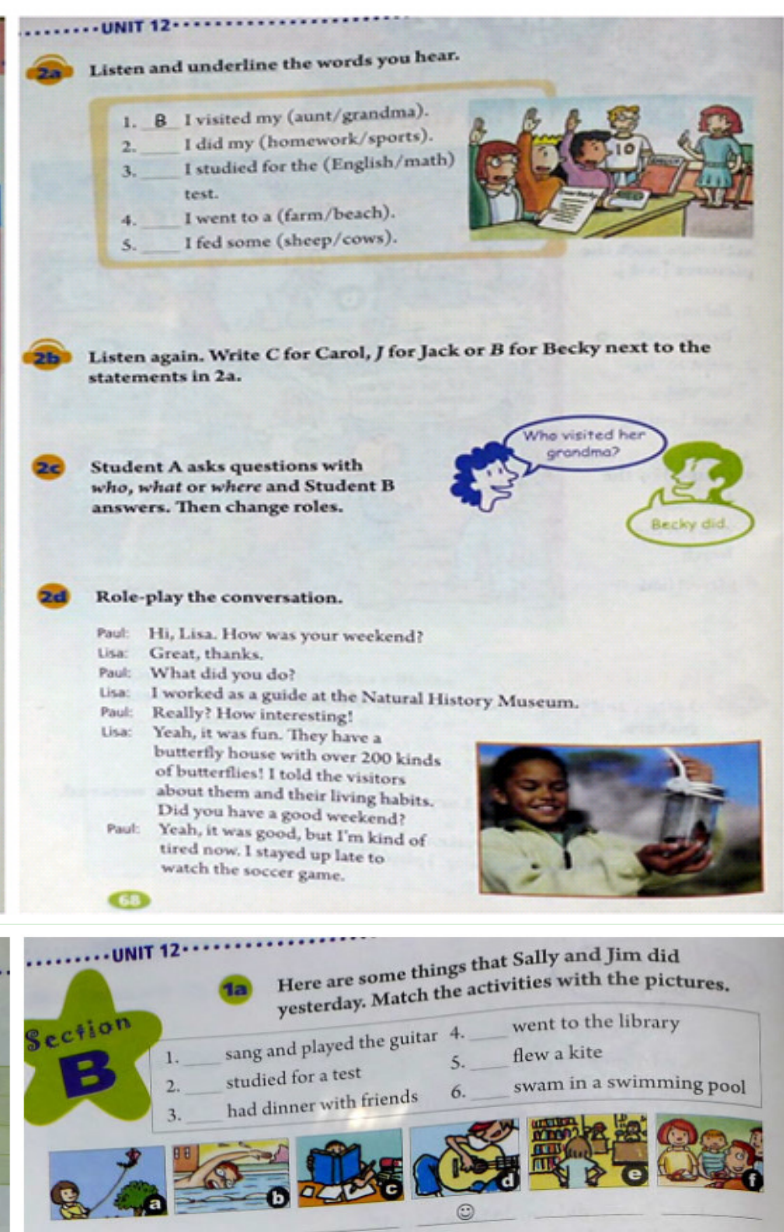

Do unhappy face $(*)$ under each picture.

(1c) Listen. What did Sally and Jim do last weekend? Complete the chart.

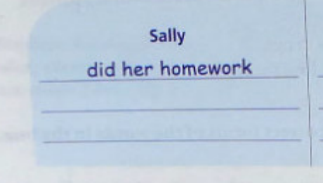

Jim

1d)

Make a conversation with a partner. Talk about what Sally and Jim did last weekend.

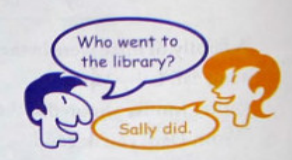

1 (1)

Make a conversation. Ask what your partner did last weekend.

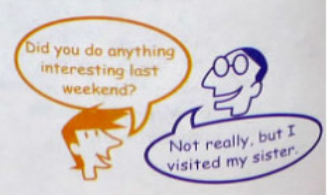



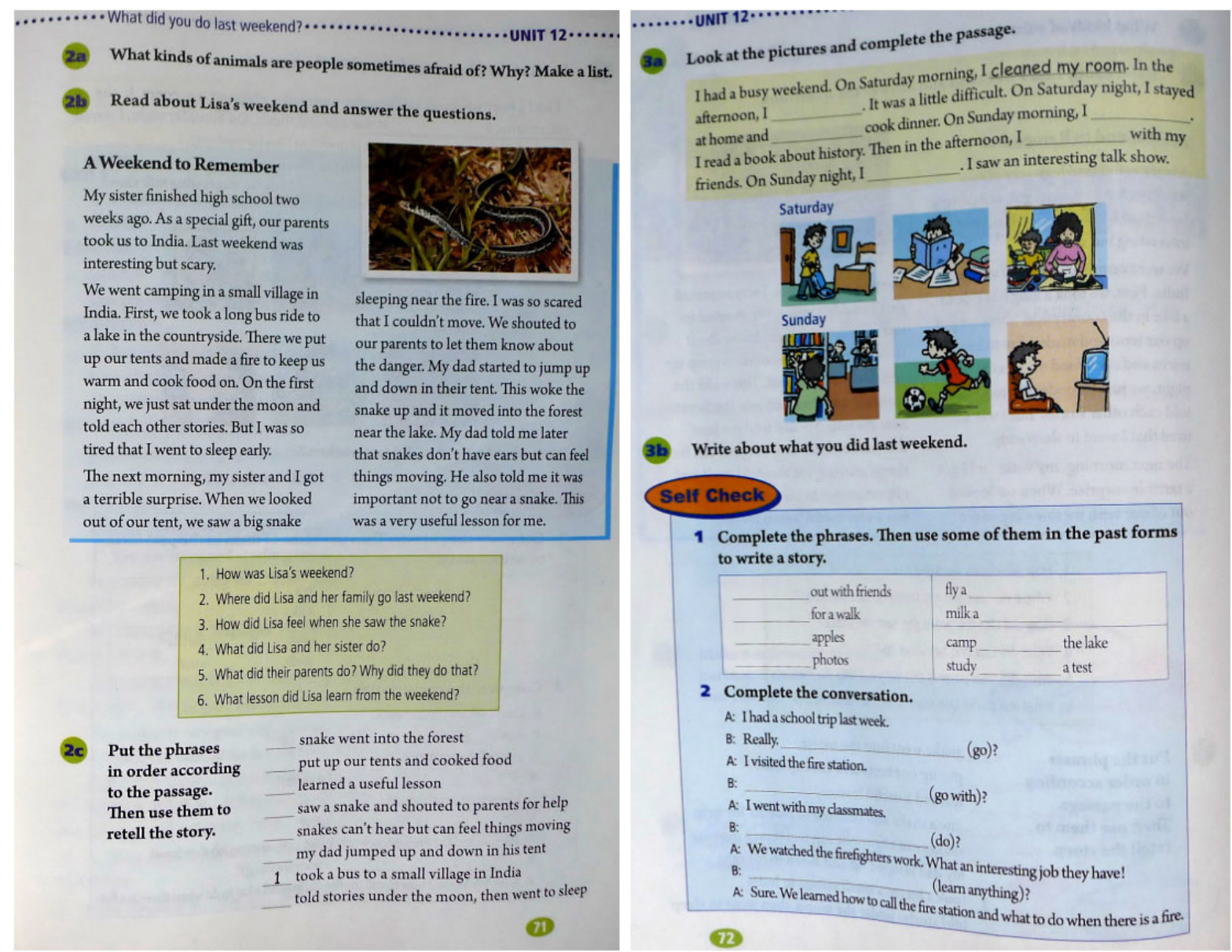

Twelve Units of the English Textbook Go for It! (Grade 7/Part 2)

“Unit 1: Can you play the guitar?";

"Unit 2: What time do you go to school?";

"Unit 3: How do you get to school?";

"Unit 4: Don't eat in class";

“Unit 5: Why do you like pandas?";

"Unit 6: I'm watching TV";

“Unit 7: It's raining!";

"Unit 8: Is there a post office near here?";

"Unit 9: What does he look like?";

"Unit 10: I'd like some noodles";

"Unit 11: How was your school trip?";

"Unit 12: What did you do last weekend?". 